\title{
PERÍCIAS EM INVESTIGAÇÃO DE PATERNIDADE
}

\author{
Sebastião André de Felice \\ Superintendente do Instituto de Medicina Social e Criminologia de \\ São Paulo (IMESC). \\ Professor Livre-docente do Departamento de Prática de Saúde \\ Pública da Faculdade de Saúde Pública da USP e Professor \\ Colaborador do Departamento de Medicina Forense e Criminologia \\ da Faculdade de Direito da USP \\ José Maria Marlet \\ Professor Titular do Departamento de Medicina Forense e \\ Criminologia da Faculdade de Direito da USP.
}

Resumo:

Os AA apresentam o princípio em que se baseiam as perícias de paternidade. Discutem o valor das probabilidades associadas a cada um dos testes rotineiramente empregados. Concluem que o teste mais eficiente é o do DNA, pois enquanto que todos os outros apenas permitem afirmar a exclusão da paternidade, este a afirma, com probabilidade de acerto de $100 \%$.

Descrevem de maneira sucinta a estrutura do DNA e a maneira de usá-la na perícia de paternidade. Analisam, ainda, as possíveis causas de erro desta técnica.

Abstract:

The AA have the principle on which the examination of paternity are based. They discuss the value of the probabilities related to each one of the tests usually used. They conclude that the most efficient tests is the DNA one, of whereas all of the others allow us to prove the exclusion of paternity, such a test proves it with $100 \%$ of certainty.

They describe the structure of the DNA and the means to use it in the examination of paternity in a simplified way. Furthermore, they analyses the possible causes of error of such a technique.

A prova de conjunção carnal não prova a fecundação. A prova de conjunção não passa de mera prova indiciatória. Por exemplo, nos casos de plurium concubentium não há como se saber qual foi o homem fornecedor do espermatozóide fecundante.

Diante da dificuldade apontada, é necessário que o juiz se socorra de provas periciais baseadas nos caracteres hereditários da criança. 
No momento da fecundação fundem-se o espermatozóide (portador de 24 cromosomos paternos) com o óvulo (possuidor de 24 cromossomos maternos, refazendo-se assim no filho a quantidade de 24 pares de cromossomos próprios da espécie humana.

As provas periciais apresentadas à Justiça, em casos de paternidade contestada, baseiam-se sempre no fato de que no filho não pode ter nenhum caráter hereditário que não provenha do pai ou da mãe.

Em aparecendo algum caracter hereditário que não se encontre nem no suposto pai e nem na mãe é incontestável que o mesmo provem do verdadeiro pai, excluindo-se assim a possibilidade da paternidade do homem suspeito.

Tradicionalmente as perícias são praticadas no sangue e são feitas na série vermelha, pesquisando-se a presença de antígenos existentes na membrana das hemácias (sistemas ABO, Rh, MNS etc.) e nos leucócitos (antígenos HLA ).

Existem outras possibilidades periciais, como as baseadas nos sistemas séricos ( $\mathrm{Gm}, \mathrm{Gc}$, nas haptaglobulinas etc.) não empregadas entre nós pela extrema complexidade técnica que demandam.

Cada um destes antígenos apresenta uma determinada probabilidade de exclusão. Estudos estatísticos extremamente rigorosos têm mostrado que 20 sistemas da série eritrocitária podem excluir acertadamente $72 \%$ de falsos pais. Acrescentando o teste do HLA alcança-se a probabilidade de exclusão dos falsos pais de aproximadamente $98 \%$.

Esta alta percentagem de exclusão leva à falsa impressão de certeza, o que está completamente errado, pois significa que sobram $2 \%$ dos homens em idade fértil que podem ser o verdadeiro pai, o que, em termos populacionais representa um número enorme de possíveis pais. Esta falha das perícias clássicas de exclusão de paternidade (séries eritrocitária e leucocitária) costuma ser suprida por provas indiciatórias. Infelizmente são sobejamente conhecidas a fragilidade das provas indiciatórias, o que, não raro, leva à atribuições de paternidade erradas, com as conseqüências sociais facilmente imagináveis.

Felizmente dispomos atualmente de uma prova de certeza absoluta de paternidade : a do DNA (ácido desoxi-ribonucleico).

O DNA é conhecido de longa data pelos geneticistas, mas foi o Prof. Alec Jeffreys, em 1985, na Inglaterra, quem simplificou as técnicas de manipulação do DNA, de maneira a torná-las acessíveis aos laboratórios não especializados em pesquisas genéticas, abrindo a possibilidade de que os estudos do DNA fossem 
aplicados para resolver problemas práticos, como os representados pelas perícias de paternidade ou de identificação médico-forense.

Vejamos em que consiste o DNA:

No interior de todas as células, com excepção das hemácias, há o núcleo, formado por um enovelado de "estruturas filiformes" chamados cromossomos. Dispomos de técnicas relativamente fáceis de desmanchar o núcleo, isolando seus cromossomos.

A matéria prima dos cromossomos é o DNA.

Os cromossomos estão formados por um par de "fitas" de aminoácidos ligados entre si, como se se tratasse de um zíper, e que adotam forma espiralada.

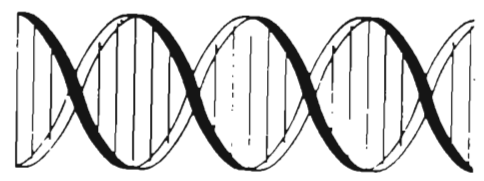

Existem quatro aminoácidos (guanina, adenina, tiamina e citosina), representados respectivamente pelas letras $\mathrm{G}, \mathrm{A}, \mathrm{T}, \mathrm{e} \mathrm{C}$, que se unem entre si sempre da seguinte maneira:

G com C

A com $T$

Assim, conhecida seqüência numa das "tiras", conhece-se a da outra.

A sequiência dos "dentes" do zíper caracteriza a mensagem genética.
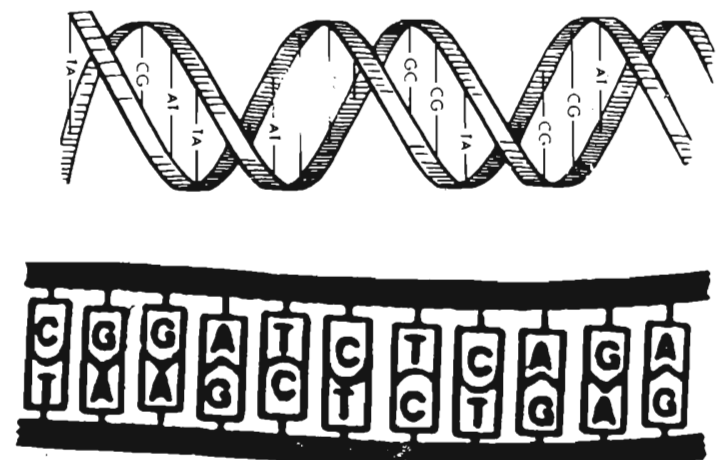
Esquematicamente podemos representá-la por

-C-C-C-G-T-A-T-C- C-C-G-G-C-C-T-T-A-T-T- A-C-G-

-G-G-G-C-A-T-A-G-G-G-C-C-G-G-A-A-T-A-A-T-G-C-

Procedimentos térmicos permitem separar as duas "fitas" de DNA, como se se abrisse o "zíper".

$\mathrm{O}$ exemplo apresentado fica:

$$
\begin{aligned}
& \text {-C-C-C-G-T-A-T-C -C-C-G-G-G-C-T-T-A-T-T- A-C-G - } \\
& \text {-G-G-G-C-A-T-A-G-G-G-C-C-C-G-A-A-T-A-A-T-G-C- }
\end{aligned}
$$

Existem diversas enzimas, chamadas de enzimas de restrição, que cortam, como se fossem tesouras químicas, os micro-satélites nos pontos em que encontrarem uma determinada seqüência de aminoácidos, assim, por exemplo, a enzima de restrição SmaI corta a cadeia de aminoácidos sempre na seqüência C-G, enquanto que a enzima de restrição TaqI o faz na seqüência T-C.

$\mathrm{Na}$ exemplo apresentado anteriormente, as enzimas de restrição SmaI e TaqI cortariam cada "fita" nos pontos

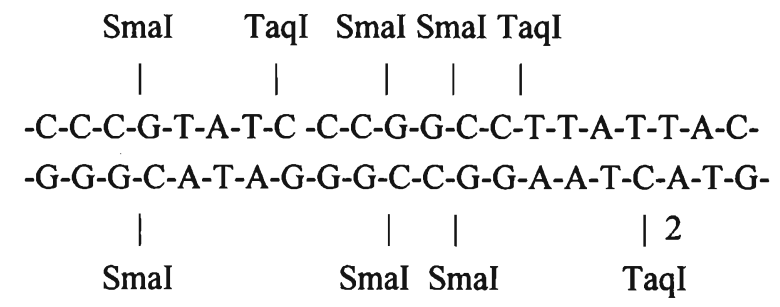

transformando a cadéia em fragmentos de restrição. No nosso exemplo os fragmentos de restrição são:

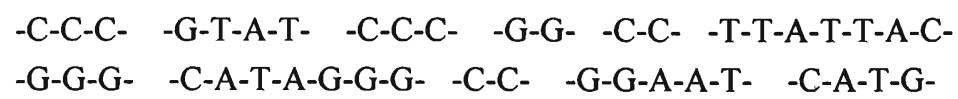

Os fragmentos de restrição têm seqüências e tamanhos muito variados. São diferentes em cada pessoa (exceto entre irmãos gêmeos univitelinos) e se transmitem seguindo as leis de Mendel.

Dispõe-se atualmente de uma téćnica, a do PCR, que permite reproduzir em poucas horas os fragmentos de restrição milhões de vezes, tornado-se possível praticar as perícias com quantidades iniciais de DNA ínfimas.

A técnica pericial segue o seguinte caminho: 
1 Isolamento do DNA do material disponível (sangue fresco ou seco, bulbo capilar, fragmento de tecido etc.

2 - Separação das "tiras" de DNA por calor.

3 - Cortar o DNA em fragmentos de restrição, mediante banho com enzimas de restrição.

4 - Hibridação: consiste em incubar os fragmentos de restrição com fragmentos de restrição preparados no laboratório e marcados com íons radioativos, chamados sondas. Cada sonda procura o segmento de restrição com o qual possa se acoplar conforme a sequêencia de aminoácidos.

DNA

Sonda

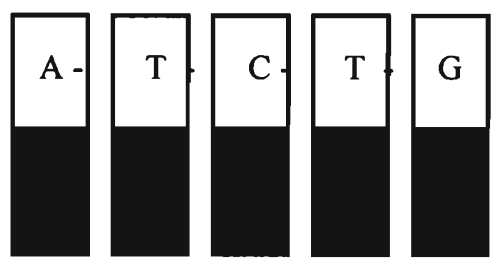

5 Eletroforese: Cada segmento de restrição refeito (original + sonda) é colocado numa superfície de gel e submetida à passagem de corrente elétrica. Os segmentos de restrição têm cargas elétricas diferentes, dependendo de seu comprimento, o que permite que se desloquem a distâncias variáveis, distribuindo-se em faixas paralelas contendo milhões de segmentos de restrição.

6 Revelação: A tira de gel é colocada em contato com uma chapa de $\mathrm{Rx}$, que fica sensibilizada pela radioatividade de cada grupo de segmentos de restrição.

$\mathrm{O}$ aspecto resultante, de maneira esquematizada é:

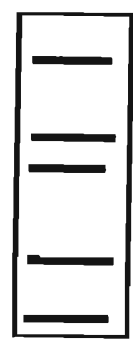

Esta imagem é parecida à seqüência de linhas usada na codificação eletrônica dos preços nos supermercados. 
Obtida a imagem de cada um dos interessados na determinação da paternidade (mãe, filho e indigitado pai), passa-se à análise dos resultados por comparação das bandas do filho com as da mãe e as do presumido pai.

Imaginemos que os resultados foram de um caso em que há três homens suspeitos de serem o pai:

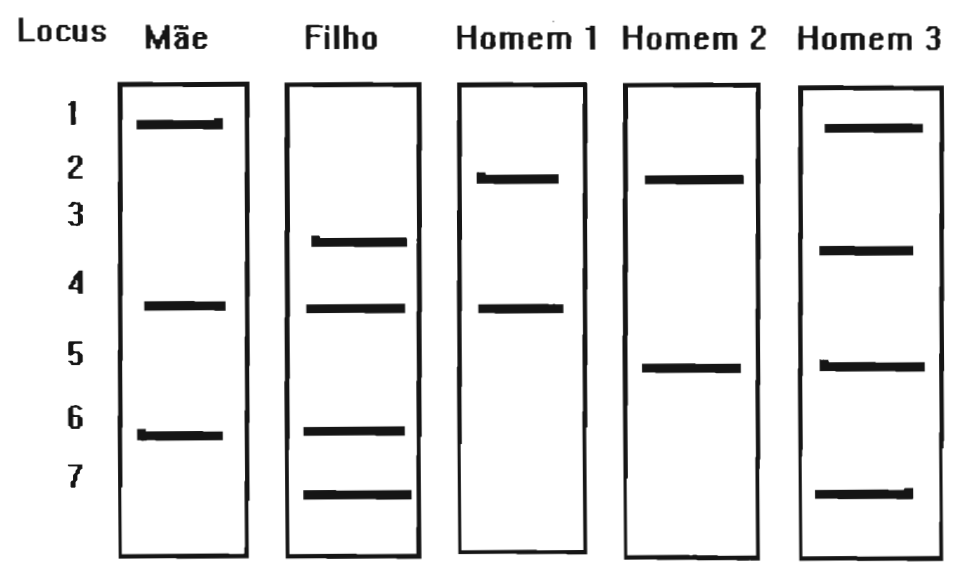


Concordâncias nos locus:

Filho e mãe $\quad: 4$ e 6

Filho e homem $1: 4$ (tanto pode ser do pai

como da mãe, logo não

pode ser levado em conta)

Filho e homem 2 : nenhuma

Filho e homem $3: 3$ e 7 .

Isto permite excluir os homens 1 e 2 como possíveis pais e afirmar a paternidade do homem 3 .

A grande diversidade na composição do DNA de uma pessoa para outra e sua transmissão hereditária segundo as leis de Mendel permite afirmar, com uma probabilidade de $99,99 \%$, isto é, praticamente com certeza, qual entre os examinados. é o pai fisiológico.

A grande vantagem do teste do DNA consiste em poder afirmar a paternidade, ao contrário do que ocorria com os testes anteriores, capazes apenas de excluí-la, mas nunca de afirmá-la.

Algumas dúvidas foram levantadas quanto à validade deste teste no mundo jurídico. Do ponto de vista teórico, nada cabe se pode objetar ao mesmo. Deve-se ressalvar, comtudo, que o teste é feito por homens e que estes são sempre faliveis.

Para se ter certeza que o teste é realmente fidedigno, deve-se ter presente:

a) A idoneidade do laboratório onde foi feita análise.

b) A procedência dos reativos empregados.

c) Se são observadas, de rotina, as normas estabelecidas por laboratórios de referência. 